\title{
Pengaruh locus of control, praktik kerja lapangan, dan informasi dunia kerja terhadap kesiapan kerja siswa kelas xii teknik instalasi tenaga listrik Smk se-Kabupaten Magetan
}

\author{
Peggy Gilang Pratama, Yuni Rahmawati *, Heru Wahyu Herwanto \\ Universitas Negeri Malang, Jl. Semarang No. 5 Malang, Jawa Timur, Indonesia \\ *Penulis korespondensi, Surel: yuni.rahmawati.ft@um.ac.id
}

Paper received: 03-01-2021; revised: 15-01-2021; accepted: 30-01-2021

\begin{abstract}
Abstrak
Kesiapan kerja merupakan keseluruhan sikap dan kondisi yang menunjukkan kematangan baik fisik, mental dan pengelaman belajar yang dimiliki seseorang dalam menghadapi suatu pekerjaan. Kesiapan kerja dapat dipengaruhi oleh beberapa faktor antara lain faktor internal dan eksternal. Kedua faktor tersebut dapat mempengaruhi kematangan seseorang dalam mempersiapkan dirinya ketika memasuki dunia kerja Penelitian yang dilakukan menggunakan pendekatan kuantitatif dengan rancangan penelitian yaitu deskriptif explanatori. Sampel dalam penelitian ini adalah siswa kelas XII Program Keahlian Teknik Tenaga Listrik SMK Se-Kabupaten Magetan sejumlah 100 siswa. Penelitian ini menggunakan kuisioner yang telah diuji validitas dan reliabilitas sebagai alat pengumpulan data. Analisis regresi sederhana digunakan untuk mengetahui adanya pengaruh tiap variabel bebas terhadap varibal terikat. Analisis regresi berganda digunakan untuk mengetahui adanya pengaruh variabel bebas secara bersama-sama terhadap variabel terikat. Hasil penelitian diketahui bahwa: (1) locus of control masuk dalam kategori sangat tinggi, (2) praktik kerja lapangan masuk dalam kategori sangat tinggi, (3) informasi dunia kerja masuk dalam kategori tinggi, (4) kesiapan kerja masuk dalam kategori sangat tinggi. Secara parsial X1 dengan Y, X2 dengan Y, X3 dengan $Y$ mempunyai pengaruh yang positif dan signifikan. Secara simultan X1, X2 dan X3 dengan $Y$ mempunyai hubungan positif dan signifikan.
\end{abstract}

Kata kunci: locus of control; praktik kerja lapangan; dan informasi dunia kerja; kesiapan kerja.

\section{Pendahuluan}

Berdasarkan data yang diperoleh dari Badan Pusat Statistik (BPS) tahun 2019 mengenai Tingkat Pengangguran Terbuka (TPT) dalam setahun terakhir, pengangguran berkurang sebanyak 50 ribu orang. Hal ini sejalan dengan TPT yang turun menjadi 5,01\% pada Februari 2019. Dilihat dari tingkat pendidikan, TPT untuk SMK masih tertinggi diantara tingkat pendidikan lain, yaitu sebesar 8,63\%. Sedangkan pengangguran di Kabupaten Magetan dari data BPS yakni dengan presentase 3,08\%. Dimana angka pengangguran tersebut di dominasi oleh siswa lulusan SMK. Berdasarkan data tersebut menunjukan bahwa tingkat pengangguran masih cukup tinggi dan sebagian besar pengangguran tersebut didominasi oleh lulusan SMK. Dengan hal ini, maka peningkatkan kesiapan kerja bagi siswa lulusan SMK perlu dilakukan dengan tepat dan maksimal.

Terdapat karakteristik psikologis dari dalam diri yang mempengaruhi kesiapan kerja seseorang salah satunya adalah locus of control. Menurut (Robbins \& Judge, 2008) menjelaskan bahwa loscus of control merupakan tingkat keyakinan setiap individu bahwa mereka adalah penentu atas nasib mereka sendiri. Dapat di artikan bahwa locus of control yakni kepercayaan diri dalam mengontrol dan menentukan nasibnya sendiri-sendiridan harus siap untuk mempertanggungjawabkan dan mengambil resiko atas apa yang telah ditentukan. Supaya peserta didik memiliki kesiapan kerja yang baik maka dibutuhkan locus of control 
untuk mengendalikan dirinya sendiri. Ketika seseorang memiliki kemampuan kendali locus of control yang baik maka akan lebih meningkatkan kesiapan kerjanya. Hal ini dipertegas penelitian yang dilakukan oleh (Muyasaroh et al., 2013), pembentukan locus of control yang baik maka dapat berpengaruh positif terhadap peningkatan kesiapan kerja siswa setelah lulus.

Dalam menyiapkan siswa yang akan terjun ke dalam dunia kerja, SMK mengadakan program praktik kerja lapangan untuk siswa yang bekerjsama dari berbagai pihak. Menurut (Larasati, 2018) praktik kerja lapangan merupakan bentuk pelatihan yang di laksanakan di lapangan yang bertujuan untuk memberikan pengalaman yang di perlukan dalam mengerjakan suatu pekerjaan tertentu. Praktik kerja lapangan merupakan wadah bagi siswa untuk belajar dan mengaplikasikan ilmu-ilmu yang dipelajarinya di kelas dan diharapkan agar siswa dapat berlatih untuk cepat,tanggap dan terampil dalam menghadapi situasi dan kondisi di dalam dunia kerja sehingga dapat meningkatkan kesiapan kerja siswa untuk memasuki dunia kerja.

Terdapat faktor lain yang berpengaruh terhadap kesiapan kerja yaitu informasi mengeni dunia kerja. Informasi dunia kerja merupakan bentuk informasi berupa wawasan, pengetahuan dan kesempatan mengenai kondisi serta peluang kerja untuk siswa dari berbagai sumber baik dari dalam sekolah maupun dari luar sekolah. Ketika semakin mudahnya kesempatan siswa dalam memilih dan mendapatkan pekerjaan, maka dalam hal ini peranan guru BK sangatlah penting. Guru BK harus ikut andil dalam pelayanan dan pendampingan ketika siswa memilih pekerjaan. Hal ini akan membantu siswa dalam memilih pekerjaan sesuai dengan bidangnya. Sehingga dengan adanya bimbingan dan pendampingan dalam menyaring informasi dunia kerja dapat meningkatkan kesiapan kerja siswa, karena memberikan gambaran mengenai perusahaan yang dipilih dan bagaimana pekerjaan dalam perusahaan tersebut.

Adapun tujuan penelitian ini untuk 1) mendeskripsikanitingkat Locus Of Control pada siswa kelas XII TITL di Kabupaten Magetan, 2) mendeskripsikan tingkat Praktik Kerja Lapngan pada siswa kelas XII TITL di Kabupaten Magetan, 3) mendeskripsikan tingkat Informasi dunia kerja pada siswa kelas XII TITL di Kabupaten Magetan, 4) mendeskripsikan tingkat kesiapan kerja siswa kelas XII TITL di Kabupaten Magetan, 5) mengungkap pengaruh locus of control terhadap kesiapan kerja siswa kelas XII TITL di Kabupaten Magetan,6) mengungkap pengaruh praktik kerja lapangan terhadap kesiapan kerja siswa kelas XII TITL di Kabupaten Magetan, 7) mengungkap pengaruh informasi dunia kerja terhadap kesiapan kerja siswa kelas XII TITL di Kabupaten Magetan, 8) mengungkap pengaruh locus of control, praktik kerja lapangan dan informasi dunia kerja terhadap kesiapan kerja siswa kelas XII TITL di Kabupaten Magetan.

\section{Metode}

Penelitian ini menggunakan metode pendekatan kuantitatif. Penelitian kuantitatif menurut (Arikunto, 2007) merupakan penelitian yang menggunakan angka-angka, dimulai dari pengumpulan data,analisis terhadap data,serta pengujian terhadap hasilnya. Rancangan peneltian ini yaitu deskriptif explanatori dengan sifat expost-fact. Menurut Noor (2012) Penelitian deskriptif adalah suatu penelitian yang medeskripsikan suatu gejala, peristiwa, dan kejadian yang terjadi. Menurut (Mardalis, 2008) penelitian eksplanatori adalah penelitian pengujian hipotesa yang menguji hubungan sebab akibat diantara variabel yang diteliti. Jadi penelitian ekplanatori dalam penelitian ini digunakan untuk menjalaskan hubungan pengaruh tiap variabel, yaitu pengaruh variabel bebas terhadap terikat. 
Populasi penelitianini adalah semua siswa kelas XII TITL SMK di Kabupaten Magetan.Teknik pengambilan sampel dalam penelitian ini menggunakan teknik proportional random sampling yaitu semua siswa kelas XII TITL SMK di Kabupaten Magetan teknik. Teknik pengambilan sampel yang akan digunakan adalah teknik Slovin dengan taraf kesalahan 5 persen yaitu 100 siswa. Instrumen yang digunakan dalam penelitian ini berupa angket atau kuesioner yang disusun menggunakan model skala likert.Teknik analisis data yang digunakan adalah: (1) uji validitas instrumen; (2) uji reliabilitas instrumen; (3) uji prasyarat meliputi uji normalitas, uji linearitas, i, uji multikolinearitas, uji heterokedastisitas; dan (4) Uji Hipotesis.

\section{Hasil dan Pembahasan}

Hasil dari analisis statistik deskripstif dengan bantuan software SPSS untuk data variabel Locus Of Control diperoleh data rata-rata sebesar 55,66 dan standart deviasi sebesar 4,81 dengan skor tertinggi 65 dan skor terendah 47 dengan sebaran frekuensi dapat dilihat pada Tabel 1 berikut.

Tabel 1. Distribusi Frekuensi Locus Of Control

\begin{tabular}{lllll}
\hline No. & Kriteria & Interval (i) & Frekuensi (f) & Persentase (\%) \\
\hline 1. & Sangat tinggi & $56-68$ & 51 & $51 \%$ \\
2. & Tinggi & $43-55$ & 49 & $49 \%$ \\
3. & Rendah & $30-42$ & 0 & $0,0 \%$ \\
4. & Sangat Rendah & $17-29$ & 0 & $0,0 \%$ \\
\hline Total & & & 46 & $100 \%$ \\
\hline
\end{tabular}

Dari tabel 1.0 disimpulkan bahwa locus of control siswa kelas XII kompetensi keahlian TITL di Kabupaten Magetan yang masuk dalam kategori Sangat tinggi sejumlah 51 responden (51\%), tinggi sejumlah 49 responden (49\%), rendah 0 responden $(0,0 \%)$, dan sangat rendah sejumlah 0 responden $(0,0 \%)$. Jadi dapat disimpulkan bahwa locus of control yang dimiliki siswa kelas XII kompetensi keahlian TITIL di Kabupaten magetan dapat dikatakan sangat tinggi. Hasil dari analisis statistik deskripstif dengan bantuan software SPSS untuk data variabel Praktik Kerja Lapangan diperoleh data rata-rata sebesar 67,47 dan standart deviasi sebesar 7,59 dengan skor tertinggi 80 dan skor terendah 53 dengan sebaran frekuensi dapat dilihat pada Tabel 2 berikut.

Tabel 2. Distribusi Frekuensi Praktik Kerja Lapangan

\begin{tabular}{lllll}
\hline No. & Kriteria & Interval (i) & Frekuensi (f) & Persentase (\%) \\
\hline 1. & Sangat tinggi & $56-68$ & 23 & $50,0 \%$ \\
2. & Tinggi & $43-55$ & 23 & $50,0 \%$ \\
3. & Rendah & $30-42$ & 0 & $0,0 \%$ \\
4. & Sangat Rendah & $17-29$ & 0 & $0,0 \%$ \\
\hline Total & & 46 & $100 \%$ \\
\hline
\end{tabular}


Dari Tabel 2 disimpulkan bahwa bahwa praktik kerja lapangan siswa kelas XII kompetensi keahlian TITL di Kabupaten Magetan yang masuk dalam kategori Sangat tinggi sejumlah 51 responden (51\%), tinggi sejumlah 49 responden (49\%), rendah 0 responden $(0,0 \%)$, dan sangat rendah sejumlah 0 responden $(0,0 \%)$. Jadi dapat disimpulkan bahwa praktik kerja lapangan yang dimiliki siswa kelas XII kompetensi keahlian TITIL di Kabupaten magetan dapat dikatakan sangat tinggi. Hasil dari analisis statistik deskripstif dengan bantuan software SPSS untuk data variabel Informasi Dunia Kerja diperoleh data rata-rata sebesar 70,68 dan standart deviasi sebesar 10,69 dengan skor tertinggi 92dan skor terendah 38 dengan sebaran frekuensi dapat dilihat pada Tabel 3 berikut.

Tabel 3. Distribusi Frekuensi Informasi Dunia Kerja

\begin{tabular}{lllll}
\hline No. & Kriteria & Interval (i) & Frekuensi (f) & Persentase (\%) \\
\hline 1. & Sangat tinggi & $99-120$ & 19 & $41,3 \%$ \\
2. & Tinggi & $76-98$ & 26 & $56,5 \%$ \\
3. & Rendah & $53-75$ & 1 & $2,2 \%$ \\
4. & Sangat Rendah & $30-52$ & 0 & $0,0 \%$ \\
\hline Total & & 46 & $100 \%$ \\
\hline
\end{tabular}

Dari Tabel 3 disimpulkan bahwa pengaruh informasi dunia kerja siswa kelas XII kompetensi keahlian TITL di Kabupaten Magetan yang masuk dalam kategori Sangat tinggi sejumlah 38 responden (38\%), tinggi sejumlah 54 responden (54\%), rendah 7 responden (7\%), dan sangat rendah sejumlah 1 responden (1\%). Jadi dapat disimpulkan bahwa pengaruh informasi dunia kerja yang dimiliki siswa kelas XII kompetensi keahlian TITIL di Kabupaten magetan dapat dikatakan sangat tinggi. Uji prasyarat yang dilakukan dengan 5 uji yaitu uji normalitas, uji linearitas, uji multikolinearitas, da uji heteroskedastisitas. Hasil uji normalitas dapat dilihat pada Tabel 4 berikut.

Tabel 4. Hasil Uji Normalitas

\begin{tabular}{lllll}
\hline No. & Variabel & Psig & Kesimpulan & Interpretasi \\
\hline 1. & Locus Of Control & 0,083 & Psig $>0,05$ & Normal \\
2. & Praktik Kerja Lapangan & 0,200 & Psig $>0,05$ & Normal \\
3. & Informasi Dunia Kerja & 0,200 & Psig $>0,05$ & Normal \\
4. & Kesiapan Kerja & 0,103 & Psig $>0,05$ & Normal \\
\hline
\end{tabular}

Hasil keputusan uji normalitas diambil dari ketentuan berikut: 1) jika nilai signifikansi $\geq 0,05(5 \%)$ maka data dapat dikatakan terdistribusi normal, dan 2) jika nilai signifikansi $\leq$ 0,05 (5\%) maka data tidak terdistribusi normal. Berdasarkan Tabel 4.0diketahui bahwa nilai signifikan setiap variabel lebih dari taraf signifikan yang telah ditentukan $(5 \%$ ataui0,05), maka dapatidisimpulkan bahwaisemua datai yang diperoleh terdistribusiinormal. Hasil uji Linearitas dapat dilihat pada Tabel 5 berikut.

Tabel 5. Hasil Uji Linearitas

\begin{tabular}{lllll}
\hline No. & Variabel & Psig & Kesimpulan & Interpretasi \\
\hline 1. & X1 dengan Y & 0,000 & Psig $<0,05$ & Linear \\
2. & X2 dengan Y & 0,000 & Psig $<0,05$ & Linear \\
3. & X3 dengan Y & 0,000 & Psig $<0,05$ & Linear \\
\hline
\end{tabular}


Hasil keputusan uji linearitas diambil dari ketentuan bahwa data dikatakan linier ketika nilai tarafsignifikansi $\leq 0,05$. Berdasarkan Tabel 5 diketahui bahwa nilai signifikanantara variableX1 denganY, dan variabel X2denganY kurang dari taraf signifikan yang telah ditentukan $(5 \%$ atau 0,05$)$, makaidapat disimpulkan bahwa hubungan secara parsial setiap variabelibebas dan variabel terikatimenunjukkan hubungan yang linear. Hasil uji multikolinearitas dapat dilihat pada Tabel 6 berikut.

Tabel 6. Hasil Uji Multikolinearitas

\begin{tabular}{llll}
\hline \multirow{2}{*}{ No. Variabel } & \multicolumn{2}{c}{ Collinearity } & Statistics \\
\cline { 3 - 4 } & & Tolerance & VIF \\
\hline 1. & Locus Of Control & 0,899 & 1,001 \\
2. & Praktik Kerja Lapangan & 0,756 & 1,329 \\
3. & Informasi Dunia Kerja & 0,735 & 1,360 \\
\hline
\end{tabular}

Hasil keputusan uji multikolinearitas diambil dari ketentuan yaitu tidak terjadimultikolinearitas jikanilai tolerance $>0,10$, dannilai $\mathrm{VIFi}<10$. Berdasarkan Tabel 6.0 dapat disimpulkanibahwa tidakiterjadiimultikolinearitas. Hasil uji heteroskedastisitas dapat dilihat pada Gambar 1 berikut.

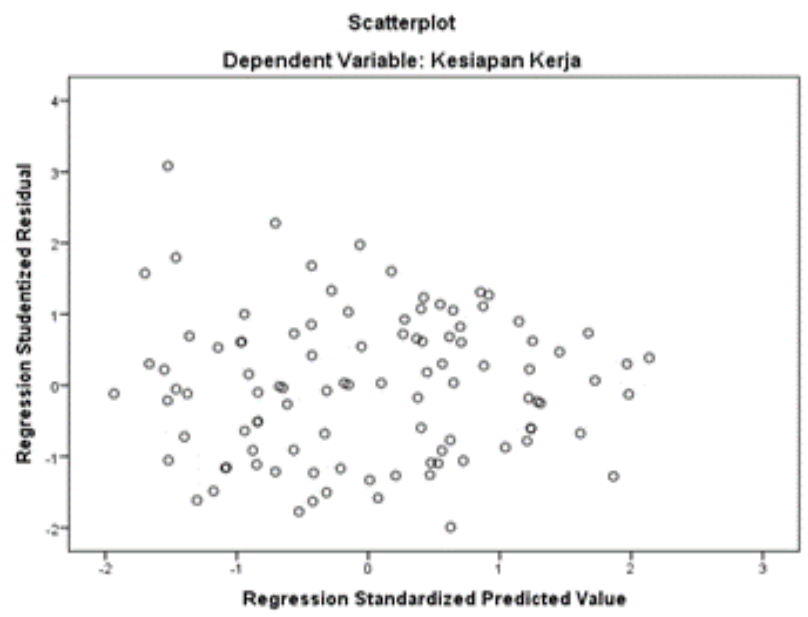

\section{Gambar 1. Hasil Uji Heteroskedastisitas}

Hasil uji heteroskedastisitas diatas menunjukkan bahwa pola yang dibentuk titik-titik dalam gambar tidak terlihat dengan jelas karena titik-titik menyebar secara rata ada yang di atas dan di bawah angka 0 pada sumbu $Y$, sehingga dapatidisimpulkan bahwa tidak terjadi heteroskedastisitas. Setelah uji prasyarat memenuhi maka dapat dilakukan pengujian hipotesis dimana hasil pengujian hipotesis digambarkan pada Tabel 8 dan 9 berikut.

Tabel 8. Hasil uji parsial

\begin{tabular}{lllll}
\hline No. & Variabel & Probabilitas & Interpretasi \\
\cline { 3 - 4 } & & Nilai signifikansi & Taraf siginifikan & \\
\cline { 3 - 4 } 1. & X1 -Y & 0,000 & 0,005 & H1 diterima \\
2. X2-Y & 0,000 & 0,005 & H1 diterima \\
3. & X3-Y & 0,000 & 0,005 & H1 diterima \\
\hline
\end{tabular}


Diketahui dari Tabel 8 bahwa nilai signifikansi antara X1,X2, X3 dengan Y yaitu 0,000<0,05 maka H0 ditolak dan H1 diterima, yang artinya bahwa terdapat pengaruh positif dan signifikan antara praktik kerja lapangan dengan kesiapan kerja siswa SMK kelas XII TITL di kabupaten Magetan.

Tabel 9. Ringkasan HasiliAnalisis Regresi

\begin{tabular}{llll}
\hline No. Variabel & \multicolumn{2}{l}{ Probabilitas } & Interpretasi \\
\cline { 3 - 3 } & & Nilai signifikansi & Taraf signikan \\
\cline { 1 - 2 } 1. X1, X2, X3 -Y & 0,000 & 0,005 & H1 diterima \\
\hline
\end{tabular}

Berdasarkan Tabel 9 bahwa nilai signifikansi yaitu 0,000<0,05 maka H0 ditolak dan H1 diterima, artinya bahwa terdapat pengauruh yang positif dan signifikan antara locus of control, praktik kerja lapangan dan informasi dunia kerja dengan kesiapan kerja siswa SMK kelas XII TITL di kabupaten Magetan. Masing-masing variabel memiliki sumbangan relatif (SR\%) dan sumbangan efektif (SE\%) terhadap pengaruhnya kepada variabel Y.HasiliSE\% dan SR\% singkatnya dapatidilihat padaiTabel 10 berikut.

Tabel 10. Sumbangan Efektif dan Sumbangan Relatif Variabel Penelitian

\begin{tabular}{lll}
\hline Prediktor & SR\% & SE\% \\
\hline X1 & $35,2 \%$ & $18,42 \%$ \\
X2 & $36,7 \%$ & $19,19 \%$ \\
X3 & $28,5 \%$ & $14,90 \%$ \\
Total & $100,4 \%$ & $52,51 \%$ \\
\hline
\end{tabular}

Berdasarkan Tabel 10.0dapat disimpulkan bahwa sumbangan relatif locus of control (X1) dengan Y sebesar 35,2\%. Sumbangan relatif praktik kerja lapangan (X2) dengan Y sebesar $36,7 \%$. Sumbangan relatif informasi dunia kerja (X3) dengan Y sebesar 28,5\%. Sedangkan untuk sumbangan efektif pada locus of control (X1) sebesar 18,42\%. Sumbangan efektif pada praktik kerja lapangan (X2) sebesar 19,19\%. Sumbangan efektif pada informasi dunia kerja (X3) 14,90\%. Berdasarkan hasil yang telah didapat dapat ditarik kesimpulan bahwa ketiga variabel bebas mempunyai pengaruh signifikan terhadap variabel terikat yaitu sebesar $52,51 \%$, dan 47,49\%dipengaruhi oleh faktor lain yang tidak diteliti pada penelitian ini.

\section{Simpulan}

Berdasarkanhasil analisa dani pembahasan yang dijelaskan di atas, makadapat diperoleh kesimpulan bahwa Locus of control pada siswa siswa kelas XII Teknik Instalasi Tenaga Listrik (TITL) SMK di kabupaten Magetan dalam kategori sangat tinggi. Tingkat locus of control secara berturut-turut dijabarkan dari tinggi ke rendah sebagai berikut: (1) locus of control internal, (2) locus of control eksternal. Praktik kerja lapangan pada siswa siswa kelas XII Teknik Instalasi Tenaga Listrik (TITL) SMK di kabupaten Magetan dalam kategori sangat tinggi. Tingkat praktik kerja lapangan secara berturut-turut dijabarkan dari tinggi ke rendah yakni sebagai berikut: (1) pengetahuan kerja, (2) ketrampilan kerja, (3) sikap kerja. Informasi dunia kerja pada siswa siswa kelas XII Teknik Instalasi Tenaga Listrik (TITL) SMK di kabupaten Magetan dalam kategori tinggi. Tingkat informasi dunia kerja secara berturut-turut dijabarkan dari tinggi ke rendah yakni sebagai berikut: (1) ruang lingkup informasi dunia kerja, (2) kualitas informasi, (3) frekuensi siswa mencari informasi. Kesiapan kerja pada siswa siswa 
kelas XII Teknik Instalasi Tenaga Listrik (TITL) SMK di kabupaten Magetan dalam kategori sangat tinggi. Tingkat kesiapan kerja secara berturut-turut dijabarkan dari tinggi ke rendah yakni sebagai berikut: (1) kesiapan secara psikis untuk bekerja, (2) kondisi fisik mendukung untuk bekerja, (3) berani mengambil bidang pekerjaan lain, (4) siap bersaing ditempat kerja

Terdapat pengaruh positif dan signifikan antara locus of control dengan kesiapan kerja siswa SMK kelas XII TITL di kabupaten Magetan. Terdapat pengaruh positif dan signifikan antara praktik kerja lapangan dengan kesiapan kerja siswa SMK kelas XII TITL di kabupaten Magetan.Terdapat pengaruh positif dan signifikan antara informasi dunia kerja dengan kesiapan kerja siswa SMK kelas XII TITL di kabupaten Magetan.Terdapat pengaruh positif dan signifikan antara locus of control, praktik kerja lapangan dan informasi dunia kerja dengan kesiapan kerja siswa SMK kelas XII TITL di kabupaten Magetan.

\section{Daftar Rujukan}

Arikunto, S. (2007). Dasar-dasar Evaluasi Pendidikan. Jakarta: Bumi Aksara. 2010. Manajemen Penelitian.

Larasati, S. (2018). Manajemen Sumber Daya Manusia. Deepublish.

Muyasaroh, H. B., \& Hamidi, N. (2013). Pengaruh pengalaman praktik kerja industri dan locus of control terhadap kesiapan kerja siswa kelas XII SMK Negeri 1 Surakarta. Jupe-Jurnal Pendidikan Ekonomi, 1(1).

Mardalis. (1995). Metode penelitian: suatu pendekatan proposal. Bumi Aksara.

Noor, J. (2011). Metodologi Penelitian. jakarta: kencana prenada media group. Poltak, L. (2017). manajemen sumber daya manusia. jakarta: bumi aksara.

Robbins, S. P., \& Judge, T. A. (2013). Organizational behavior (Vol. 4). New Jersey: Pearson Education. 